\title{
Review \\ Reappraising the Role of Allogeneic Hematopoietic Stem Cell Transplantation in Relapsed and Refractory Hodgkin's Lymphoma: Recent Advances and Outcomes
}

\author{
Taha Al-Juhaishi ${ }^{1, *}$, Azra Borogovac ${ }^{1}$ (D), Sami Ibrahimi ${ }^{1}$, Matthew Wieduwilt ${ }^{1}$ and Sairah Ahmed ${ }^{2}$ (D) \\ 1 Stephenson Cancer Center, University of Oklahoma, Oklahoma City, OK 73104, USA; \\ Azra-Borogovac@ouhsc.edu (A.B.); Sami-Ibrahimi@ouhsc.edu (S.I.); Matthew-Wieduwilt@ouhsc.edu (M.W.) \\ 2 MD Anderson Cancer Center, University of Texas, Houston, TX 77030, USA; sahmed3@mdanderson.org \\ * Correspondence: Taha-aljuhaishi@ouhsc.edu; Tel.: +1-40527-18001
}

Citation: Al-Juhaishi, T.; Borogovac,

A.; Ibrahimi, S.; Wieduwilt, M.; Ahmed, S. Reappraising the Role of Allogeneic Hematopoietic Stem Cell Transplantation in Relapsed and Refractory Hodgkin's Lymphoma: Recent Advances and Outcomes. J. Pers. Med. 2022, 12, 125. https:// doi.org/10.3390/jpm12020125

Academic Editor: Michael Uhlin

Received: 22 November 2021

Accepted: 10 January 2022

Published: 18 January 2022

Publisher's Note: MDPI stays neutral with regard to jurisdictional claims in published maps and institutional affiliations.

Copyright: (c) 2022 by the authors. Licensee MDPI, Basel, Switzerland. This article is an open access article distributed under the terms and conditions of the Creative Commons Attribution (CC BY) license (https:// creativecommons.org/licenses/by/ $4.0 /)$.

\begin{abstract}
Hodgkin's lymphoma is a rare yet highly curable disease in the majority of patients treated with modern chemotherapy regimens. For patients who fail to respond to or relapse after initial systemic therapies, treatment with high-dose chemotherapy and autologous hematopoietic stem cell transplantation can provide a cure for many with chemotherapy-responsive lymphoma. Patients who relapse after autologous transplant or those with chemorefractory disease have poor prognosis and represent a high unmet need. Allogeneic hematopoietic stem cell transplantation provides a proven curative therapy for these patients and should be considered, especially in young and medically fit patients. The use of newer agents in this disease such as brentuximab vedotin and immune checkpoint inhibitors can help bring more patients to transplantation and should be considered as well.
\end{abstract}

Keywords: Hodgkin's lymphoma; high-dose chemotherapy; autologous hematopoietic stem cell transplant; allogeneic hematopoietic stem cell transplant

\section{Introduction}

Hodgkin's lymphoma (HL) is a rare lymphoma of B-cell origin which consists of two subtypes: classical Hodgkin's lymphoma (cHL; around 90\% of all HL cases), which is further subdivided based on histological findings into nodular sclerosis, mixed cellularity, lymphocyte-rich, and lymphocyte depleted variants; and nodular lymphocyte-predominant Hodgkin lymphoma (up to 10\% of all HL cases) [1]. HL affects 8000-9000 patients in the US per year, and the more common cHL subtype is considered as a highly curable B-cell malignancy when treated with combination chemotherapy, with or without the addition of radiotherapy [2]. It is estimated that up to $10 \%$ of HL cases are refractory to initial therapy, and up to 30\% relapse after initial response; however, approximately half of these patients can still be cured using high-dose chemotherapy and autologous hematopoietic stem cell transplant (AHSCT) [2-5]. For those who are not candidates for AHSCT or whose disease relapses afterwards, the prognosis is grim. Despite the success of the antibodydrug conjugate brentuximab vedotin and immune checkpoint inhibitors in the treatment of relapsed and refractory disease, their curative potential is debatable and the majority of patients eventually progress [6].

Allogeneic hematopoietic stem cell transplantation (AlloHSCT) is a known curative therapeutic option for a variety of hematologic and immunologic conditions. More than a decade of progress has made this modality safer and accessible to more patients worldwide [7]. The benefits of AlloHSCT go beyond the anticancer effects of high-dose chemotherapy and radiotherapy, to the more durable graft-versus-lymphoma phenomenon [8-10]. Furthermore, the recognition of the benefits of graft-versus-lymphoma effects has allowed clinicians to use lower doses of chemo- or radiotherapy (reduced-intensity conditioning, RIC) with a reduction in toxicity while achieving good outcomes. This in turn has decreased 
the morbidity and mortality of AlloHSCT and permitted its use in older, less fit and heavily pre-treated patients [11]. In this review, we will discuss the development and evidence of AlloHSCT in the treatment of cHL including our approach to utilizing this potentially curative therapy. Due to the differences in disease biology and treatment approaches in nodular lymphocyte-predominant HL, this review will not address that subtype and only focus on classical Hodgkin's lymphoma (cHL).

\section{Disease Failure after Autologous Stem Cell Transplant}

Approximately up to $10 \%$ of early-stage (non-bulky stage I or II by the Ann Arbor system) disease and about 20-30\% of advanced-stage disease treated with modern chemotherapy regimens can be refractory or relapse after initial response [12]. Despite all the progress in the field, the standard-of-care-therapy approach remains centered around using high-dose chemotherapy and AHSCT in patients with lymphoma that is responsive to chemotherapy (referred to as chemosensitive disease) [13]. This approach can potentially cure close to $50 \%$ of these patients, as shown in several randomized trials and a meta-analysis that clearly described the benefits of AHSCT in this setting [4,5,14-18]. Several studies have tried to identify the disease factors that could predict relapse after AHSCT $[19,20]$. One important predictor of relapse in these studies was the duration of lymphoma remission after initial chemotherapy, wherein relapse within 12 months of initial treatment was associated with a higher risk of relapse. Other risk factors included primary refractory disease, extranodal disease, bulky disease, active disease at the time of transplant and the presence of B symptoms from lymphoma. Identification of these high-risk features allowed clinical investigators to develop protocols for post-transplant maintenance therapies to address this unmet need.

One important and successful example of this was the international randomized phase 3 AETHERA study [21]. This study randomized high-risk HL patients post-transplant, who would receive either a placebo or brentuximab vedotin for a total of up to $16 \mathrm{cy}-$ cles. Brentuximab vedotin (BV) is an antibody-drug conjugate that targets CD30 on the surface of the malignant Reed-Sternberg cell; the antibody is linked to a microtubule inhibitor called monomethyl auristatin E. The binding of BV to CD30 on the tumor cell membrane triggers a cascade of events that ultimately results in apoptotic death of the CD30-expressing cell. Prior to the AETHERA study, BV was already shown to be effective in treatment of relapsed/refractory $\mathrm{CHL}$, both as a single agent and in combination with other chemotherapy agents [22]. High-risk patients were defined as having disease refractory to frontline therapy, progression within 12 months from the end of frontline therapy, or having extranodal relapsed disease. This maintenance approach led to improvement in 5-year progression-free survival (PFS) from $41 \%$ with a placebo to $59 \%$ with BV, with a hazard ratio (HR) of 0.521 . No benefit in overall survival (OS) has been reported yet. Of note, more patients in the placebo arm underwent AlloHSCT (23 vs. 12). These results led to the approval of BV maintenance indication by the US Food and Drug Administration (FDA) in 2015. A recent small phase 2 study explored the addition of checkpoint inhibitor nivolumab to BV while shortening the maintenance treatment duration to only eight cycles. The study enrolled 59 high-risk patients with criteria similar to that of AETHERA. The 18-month PFS and OS were reported to be $95 \%$ and $98 \%$, respectively, as only one patient relapsed. Toxicities were consistent with the known effects of these agents, with neuropathy and neutropenia being the most common in this case [23].

\section{Role of Allogeneic HSCT in Relapsed/Refractory HL}

The prognosis of patients who relapse after AHSCT is poor. Studies have shown that the median survival for these patients is around 2.4 years [24,25]. Outcomes seem to have improved over the last three decades but a shorter time to relapse post-AHSCT was associated with worse median survival post-progression (median post progression survival of about 1 year for those who relapsed within 12 months of AHSCT) [25]. The loss of life and loss to society are significant as many of these patients are young adults. A 
select group of these patients with relapsed and refractory HL can benefit from the curative potential of AlloHSCT, as shown in studies dating back to the 1980s [26]. Similar to the graft-versus-leukemia effects seen in myeloid neoplasms, a graft-versus-lymphoma (GVL) effect was described by several groups $[8,27,28]$. The evidence for GVL in cHL comes from several indirect observations. These include induction of remission by reducing immunosuppression post-transplant, or by using donor lymphocyte infusion. Moreover, the fact that reduced-intensity conditioning transplants can induce remissions in relapsed or refractory disease is a good illustration of the strength of GVL. AlloHSCT is also associated with significant toxicities, including graft-versus-host disease (GVHD), which could increase non-relapse mortality risk. GVHD, and especially the chronic GVHD, has been shown to be associated with lower risk of relapse, which may reflect the benefits of graft-mediated immune surveillance in the prevention of lymphoma relapse [10,29]. Given the lack of randomized prospective trials evaluating the role of AlloHSCT in cHL, multiple retrospective, small prospective phase 2 and registry studies have shown the benefit of this procedure in selected fit patients with relapsed disease [30]. Nevertheless, the optimal timing of AlloHSCT and appropriate group of patients remain an open debate between experts in the field and many have advocated to reserve this therapy for patients that relapse post-AHSCT [31,32]. One of the largest phase 2 studies of AlloHSCT in cHL was conducted by the Spanish lymphoma group (GELTAMO) and the European Society for Blood and Marrow Transplantation (EBMT). The study included 78 patients with relapsed cHL and showed 1-year and 4-year PFS of $48 \%$ and $24 \%$, respectively. The 1-year and 4 -year OS were $71 \%$ and $43 \%$, respectively, and NRM was $17 \%$ at 2 years. Chronic GVHD was associated with lower risk of relapse again, indicating the benefits of a GVL effect [33]. A summary of the other key studies that evaluated the role of AlloHSCT in cHL is shown in Table 1.

Table 1. Summary of the key studies evaluating the role of AlloHSCT in cHL.

\begin{tabular}{|c|c|c|c|c|c|c|c|}
\hline Study & Type & $\begin{array}{c}\text { Number of } \\
\text { Patients }\end{array}$ & $\begin{array}{c}\text { Prior } \\
\text { AHSCT }\end{array}$ & Donor Type & Conditioning & PFS & OS \\
\hline $\begin{array}{c}\text { Sureda et al. } \\
\text { [34] }\end{array}$ & $\begin{array}{l}\text { Retrospective } \\
\text { registry } \\
(\mathrm{EBMT})\end{array}$ & 168 & $52 \%$ & $\begin{array}{l}\text { MSD for more } \\
\text { than } 70 \% \text {, rest } \\
\text { are MUD }\end{array}$ & $\begin{array}{c}\text { MAC } 47 \%, \text { RIC } \\
53 \%\end{array}$ & $\begin{array}{c}20 \% \text { MAC and } \\
18 \% \text { RIC at } 5 \\
\text { years }\end{array}$ & $\begin{array}{c}22 \% \text { MAC and } \\
28 \% \text { RIC at } 5 \\
\text { years }\end{array}$ \\
\hline $\begin{array}{l}\text { Anderlini et al. } \\
{[35]}\end{array}$ & $\begin{array}{l}\text { Single center } \\
\text { prospective }\end{array}$ & 58 & $83 \%$ & $\begin{array}{c}\text { MSD } 43 \%, 57 \% \\
\text { MUD }\end{array}$ & $\begin{array}{c}\text { RIC } 100 \% \\
\text { (fludarabine and } \\
\text { Melphalan) }\end{array}$ & $32 \%$ at 2 years & $64 \%$ at 2 years \\
\hline $\begin{array}{l}\text { Robinson et al. } \\
{[36]}\end{array}$ & $\begin{array}{l}\text { Retrospective } \\
\text { registry } \\
(\mathrm{EBMT})\end{array}$ & 285 & $80 \%$ & $\begin{array}{c}\text { MSD 60\%, MUD } \\
33 \%\end{array}$ & $\begin{array}{c}\text { RIC } 100 \% \\
\text { Fludarabine based } \\
(79.5 \%), \text { low dose } \\
\text { TBI }(16 \%)\end{array}$ & $25 \%$ at 3 years & $29 \%$ at 3 years \\
\hline $\begin{array}{c}\text { Devetten et al. } \\
\text { [37] }\end{array}$ & $\begin{array}{l}\text { Retrospective } \\
\text { registry } \\
\text { (CIBMTR) }\end{array}$ & 143 & $89 \%$ & $\begin{array}{l}\text { Unrelated 100\% } \\
\text { (matched in 77\%) }\end{array}$ & $\begin{array}{l}\text { RIC/NMA } 100 \% \\
\text { Melphalan based } \\
34 \%\end{array}$ & $20 \%$ at 2 years & $37 \%$ at 2 years \\
\hline $\begin{array}{c}\text { Marcais et al. } \\
{[38]}\end{array}$ & $\begin{array}{l}\text { Multicenter } \\
\text { retrospective in } \\
\text { France }\end{array}$ & 191 & $92 \%$ & $\begin{array}{c}\text { MSD 60\%, MUD } \\
40 \%\end{array}$ & $\begin{array}{l}\text { RIC } 100 \% \\
\text { Fludarabine and } \\
\text { busulfan in } 36 \%\end{array}$ & $39 \%$ at 3 years & $63 \%$ at 3 years \\
\hline Kako et al. [39] & $\begin{array}{l}\text { Retrospective } \\
\text { registry } \\
\text { (Japanese } \\
\text { society for } \\
\text { HSCT) }\end{array}$ & 122 & $67 \%$ & $\begin{array}{c}\text { MSD 39\% MUD } \\
17 \%\end{array}$ & MAC 30\% RIC 62\% & $31 \%$ & $66 \%$ at 3 years \\
\hline $\begin{array}{l}\text { Sarina et al. } \\
{[40]}\end{array}$ & $\begin{array}{l}\text { Retrospective } \\
\text { multicenter in } \\
\text { Italy }\end{array}$ & 104 & $100 \%$ & $\begin{array}{c}\text { MSD 55\% MUD } \\
32 \%\end{array}$ & $\begin{array}{c}\text { RIC } 100 \% \\
\text { (Fludarabine based } \\
\text { in } 100 \% \text { ) }\end{array}$ & $31 \%$ at 2 years & $57 \%$ at 2 years \\
\hline
\end{tabular}




\section{Role of the Conditioning Regimen}

Myeloablative conditioning (MAC) has historically been the preferred conditioning intensity for aggressive hematologic malignancies. This is partially related to the idea of overcoming chemoresistance by increasing the total systemic dose to the highest possible amount while avoiding significant damage to organs other than the marrow. This practice in turn restricted the utilization of AlloHSCT to fit and young patients, as high morbidity and mortality are associated with this approach. The development of reduced intensity conditioning (RIC) is a major landmark in the progress of the transplant field. It expanded the eligibility to many more patients and highlighted the anticancer properties of a healthy donor immune system $[36,41]$

A study using the international bone marrow transplant registry (IBMTR), which included 114 patients with lymphoma who received MAC AlloHSCT, showed 3-year transplant-related mortality (TRM) of $22 \%$. The rate of disease progression at 3 years was noted to be $52 \%$. There were no differences seen in TRM, PFS and OS between HL and the other lymphoma types [42]. As alluded to before, the study by the Spanish group and the EBMT, which included 78 patients with cHL treated with mostly fludarabine and melphalan reduced intensity conditioning followed by matched related or unrelated AlloHSCT, showed 1-year non-relapse mortality (NRM) of 15\%. The 4-year PFS and OS were $24 \%$ and $43 \%$. Being in remission at the time of transplant and development of chronic GVHD were associated with lower risk of relapse [33].

Overall, these studies highlight a common theme in the field of hematopoietic stem cell transplantation, which is balancing the anticancer benefits of MAC against the increased risk of associated non-relapse mortality. The role of maintenance therapies in cHL postAlloHSCT remains to be investigated. One potential area that is worth exploring is the role of maintenance therapies after RIC AlloHSCT and whether this strategy could help decrease the risks of relapse and NRM, especially for those with high-risk and active disease at the time of transplant.

\section{Role of Alternative Donor HSCT in Relapsed or Refractory cHL}

The rise of alternative donors, such as haploidentical AlloHSCT donors and umbilical cord units, have further expanded the availability of transplantation to additional groups of patients [43,44]. Minorities and people in developing countries are particularly underrepresented in, or have no access to, national donor registries. The EBMT and Eurocord investigated the benefits of umbilical cord blood (UCB) transplants in a large registry study of 131 adult patients with HL. A total of $117(89 \%)$ of the patients were able to engraft with a median time of 18 days (range, 6-61). The 4-year relapse rate, NRM, PFS and OS were $44 \%, 31 \%, 26 \%$, and $46 \%$, respectively. Having residual disease at the time of transplant was associated with worse outcomes, while receiving RIC regimen of cyclophosphamide, fludarabine, and low dose total body irradiation was associated with better PFS and OS in multivariate analysis [45].

In terms of haploidentical transplants, the advent of the use of post-transplant cyclophosphamide in the prevention of GVHD has made this modality an acceptable standard of care therapy for many hematologic diseases [46]. Several retrospective studies and at least one systematic review have suggested better PFS with haploidentical AlloHSCT compared to HLA-matched transplants in cHL [41,47-49]. This approach was further evaluated by larger registry-based studies using both CIBMTR and EBMT data. In the EBMT study, they compared patients who received haploidentical AlloHSCT with those that had matched sibling or unrelated donor transplants. A total of $90 \%$ of the patients in the haploidentical AlloHSCT group received RIC regimens and 100\% had post-transplant cyclophosphamide, as expected. The composite endpoint of extensive-GVHD and relapse-free survival was better with haploidentical AlloHSCT compared to a matched-sibling donor (MSD), but similar compared to a matched-unrelated donor (MUD) (40\% for haploidentical, 28\% for MSD, and $38 \%$ for MUD). The 2-year relapse rate, PFS and OS were $39 \%, 43 \%$, and $67 \%$, respectively. Multivariate analysis showed haploidentical AlloHSCT to have a lower relapse rate 
compared to MSD, but one that is not significantly different from MUD transplants [50]. In the CIBMTR study, investigators compared 139 patients receiving haploidentical AlloHSCT to 457 others that had MSD transplants. All haploidentical AlloHSCT patients received RIC regimens and post-transplant cyclophosphamide for GVHD prophylaxis. They found no significant differences in PFS or OS; however, haploidentical AlloHSCT had lower risk of relapse. Haploidentical AlloHSCT also had a higher risk of acute GVHD, but a lower risk of chronic GVHD. The 3-year relapse rate, NRM, PFS and OS were $45 \%, 22 \%$, 33\%, and $49 \%$, respectively [51]. Another recent small retrospective study evaluated the outcomes of haploidentical AlloHSCT in patients with active refractory $\mathrm{cHL}$ who received a salvage transplant with fludarabine and melphalan-based conditioning. This study included 8 patients treated at MD Anderson Cancer Center in the US and 7 patients treated at Fundeni Clinical Institute in Romania. They reported an overall response rate of $100 \%$, with a 5-year PFS of $42.6 \%$ and a 5 -year OS of $60.9 \%$. The 5 -year NRM was found to be $21.3 \%$, but with $0 \%$ treatment-related mortality (one patient died of lung cancer more than 50 months after transplant). All relapses happened within the first year of transplant. This study, albeit small, shows very encouraging data in a difficult-to-treat group of patients [52].

The data discussed above show that alternative donor transplants are feasible and can provide durable benefits similar to sibling or matched unrelated donors. Of interest is the lower risk of relapse noted with haploidentical AlloHSCT in cHL. However, due to retrospective nature of all of these studies, this finding remains hypothesis generating and warrants validation in prospective trials.

\section{Checkpoint Inhibitors and Graft-Versus-Host Disease}

Immune checkpoint inhibitors are one of the most successful types of therapies in modern oncology, especially in solid tumors [53-55]. They have shown to be active in relapsed and refractory $\mathrm{cHL}$ in multiple prospective studies, and the FDA has approved two PD-1 inhibitors, pembrolizumab and nivolumab, for these indications [56]. Several reports have suggested that AlloHSCT in the setting of prior exposure to PD-1 inhibition may be associated with higher than normal rates of early transplant-related complications, of which the most important was severe acute GVHD. [57-59]. These results prompted a warning from the FDA to use caution using PD-1 blockade as a bridge to AlloHSCT. A systematic review of 122 patients who had received AlloHSCT after checkpoint inhibitors compared to a control group of 978 patients showed higher risk of grade III/IV acute GVHD (28\% vs. $8 \%, p=0.02)$ but similar rates of chronic GVHD (26\% vs. $29 \%, p=0.82)$. Non-relapse mortality was similar between the two groups (15\% vs. $19 \%, p=0.35)$ [60]. Another study evaluated the effects of checkpoint inhibitors before and after AlloHSCT in patients with hematologic malignancy; the 107 patients that received these drugs prior to transplant and the 176 that received them afterwards were included in this analysis. cHL was the most common disease in both groups. In the group that received checkpoint inhibitors before AlloHSCT, they reported rates of acute GVHD, chronic GVHD, and GVHD-related mortality to be $56 \%, 29 \%$ and $11 \%$, respectively. In the group that received checkpoint inhibitors after AlloHSCT, these rates were 14\%, 9\%, and 7\%, respectively [61]. A recent international retrospective study of 209 patients with cHL who underwent AlloHSCT after PD-1 inhibitors showed similar results with grade III/IV acute GVHD of 15\%, 2-year chronic GVHD of 34\%, and 2-year NRM of $14 \%$. Interestingly, the study showed that longer duration between PD-1 exposure and AlloHSCT and the use of post-transplant cyclophosphamide were both associated with better outcomes [62]. Collectively, these data suggest higher risk of complications when immune checkpoint inhibitors are used in the peri-transplant setting and therefore additional mitigation strategies are needed for safer delivery of AlloHSCT to these patients. The use of post-transplant cyclophosphamide for GVHD prophylaxis in this setting is of interest and warrants further investigation. 


\section{Authors' Approach to AlloHSCT in HL}

We recommend high-dose myeloablative chemotherapy followed by autologous stem cell rescue as standard second (or beyond second if not attempted before) line of therapy for patients with relapsed chemosensitive disease. We prefer autologous over allogeneic stem cell transplants for patients with no prior history of transplants due to lower associated toxicities. For those with disease refractory to chemotherapy, we recommend incorporation of brentuximab vedotin or checkpoint inhibitor-based regimens, then proceeding to autologous stem cell transplant, preferably in a positron emission tomography (PET) negative complete remission if able. If the disease is refractory to approved agents, then we recommend clinical trials with investigational agents if available. If no clinical trials are available, then additional attempts of chemotherapy incorporating other active chemotherapy agents or radiation could be considered. Responses in the settings are usually transient and thus consolidation with allogeneic stem cell transplantation is highly recommended. We recognize the potentially lower risk of relapse with haploidentical donor transplants compared to other donors, however due to the retrospective nature of the data and lack of clear survival benefit, we do not preferentially recommend haploidentical donors over HLA-matched donor sources. We recommend reduced-intensity conditioning regimens, such as the combination of fludarabine and melphalan, for most patients due to lower risks of transplant-associated mortality. We recommend using a post-transplant cyclophosphamide approach in patients with heavy exposure to immune checkpoint inhibitors. We do also advise a few weeks' wash-out period before transplant for patients on checkpoint inhibitor therapy, while acknowledging the lack of strong data to support this recommendation. For patients with relapsed disease after AlloHSCT or those unable to receive one, we recommend clinical trials with promising investigational therapies, which also include CD30-directed chimeric antigen receptor therapy and other cellular therapy modalities such as the combination of NK-cell therapy with AFM13 monoclonal antibodies [63,64].

\section{Conclusions}

While cHL is a rare and generally curable lymphoma for the majority of patients, there remains a gap in highly efficacious therapy for patients that experience relapsed or refractory disease. Despite the tremendous progress made in understanding this disease, high-dose chemotherapy and autologous stem cell transplant remain the most proven curative therapy for patients whose disease responds to salvage systemic therapies. Relapses after autologous stem transplant should be treated on clinical trials when possible, or with strong consideration for consolidation with reduced intensity conditioning allogeneic stem cell transplantation, using the best available donor. The role of haploidentical transplant in prevention of relapse compared to other types of donors is worth further investigation in prospective randomized trials.

Author Contributions: Conceptualization, T.A.-J. and S.A.; investigation, T.A.-J. and S.A.; project administration, T.A.J. and S.A.; writing — original draft preparation, T.A.-J. and S.A.; writing-review and editing, A.B., S.I. and M.W.; supervision, S.A. All authors have read and agreed to the published version of the manuscript.

Funding: This research received no external funding.

Institutional Review Board Statement: Not applicable.

Informed Consent Statement: Not applicable.

Data Availability Statement: Not applicable.

Conflicts of Interest: T.A.-J.: none; A.B.: none; S.I.: divested stock in Karyopharm Therapeutics; M.W.: Ad boards-Gilead/Kite, Servier, stock-Reata; S.A.: funding from SeaGen, Tessa Therapeutics, Chimagen, Merck, Xencor; served on advisory boards for SeaGen; honoraria from Novartis, Sanofi, SeaGen. The founding sponsors had no role in the design of the study; in the collection, analyses, or interpretation of data; in the writing of the manuscript, and in the decision to publish the results. 


\section{References}

1. Wang, H.W.; Balakrishna, J.P.; Pittaluga, S.; Jaffe, E.S. Diagnosis of Hodgkin lymphoma in the modern era. Br. J. Haematol. 2019, 184, 45-59. [CrossRef]

2. Ansell, S.M. Hodgkin lymphoma: 2018 update on diagnosis, risk-stratification, and management. Am. J. Hematol. 2018, 93, 704-715. [CrossRef]

3. Von Tresckow, B.; Engert, A. The role of autologous transplantation in Hodgkin lymphoma. Curr. Hematol. Malig. Rep. 2011, 6, 172-179. [CrossRef]

4. Chopra, R.; McMillan, A.; Linch, D.; Yuklea, S.; Taghipour, G.; Pearce, R.; Patterson, K.; Goldstone, A. The place of high-dose BEAM therapy and autologous bone marrow transplantation in poor-risk Hodgkin's disease. A single-center eight-year study of 155 patients. Blood 1993, 81, 1137-1145. [CrossRef]

5. Schmitz, N.; Pfistner, B.; Sextro, M.; Sieber, M.; Carella, A.M.; Haenel, M.; Boissevain, F.; Zschaber, R.; Müller, P.; Kirchner, H.; et al. Aggressive conventional chemotherapy compared with high-dose chemotherapy with autologous haemopoietic stem-cell transplantation for relapsed chemosensitive Hodgkin's disease: A randomised trial. Lancet 2002, 359, 2065-2071. [CrossRef]

6. Connors, J.M.; Cozen, W.; Steidl, C.; Carbone, A.; Hoppe, R.T.; Flechtner, H.-H.; Bartlett, N.L. Hodgkin lymphoma. Nat. Rev. Dis. Prim. 2020, 6, 61. [CrossRef]

7. Singh, A.K.; McGuirk, J.P. Allogeneic stem cell transplantation: A historical and scientific overview. Cancer Res. 2016, 76, 6445-6451. [CrossRef]

8. Butcher, B.W.; Collins, R.H. The graft-versus-lymphoma effect: Clinical review and future opportunities. Bone Marrow Transpl. 2005, 36, 1-17. [CrossRef]

9. Shah, G.L.; Moskowitz, C.H. Transplant strategies in relapsed/refractory Hodgkin lymphoma. Blood 2018, 131, 1689-1697. [CrossRef]

10. Brierley, C.K.; Jones, F.M.; Hanlon, K.; Peniket, A.J.; Hatton, C.; Collins, G.P.; Schuh, A.; Medd, P.; Clark, A.; Ward, J.; et al. Impact of graft-versus-lymphoma effect on outcomes after reduced intensity conditioned-alemtuzumab allogeneic haematopoietic stem cell transplantation for patients with mature lymphoid malignancies. Br. J. Haematol. 2019, 184, 547-557. [CrossRef]

11. Perales, M.A.; Ceberio, I.; Armand, P.; Burns, L.J.; Chen, R.; Cole, P.D.; Evens, A.M.; Laport, G.G.; Moskowitz, C.H.; Popat, U.; et al. Role of Cytotoxic Therapy with Hematopoietic Cell Transplantation in the Treatment of Hodgkin Lymphoma: Guidelines from the American Society for Blood and Marrow Transplantation. Biol. Blood Marrow Transpl. 2015, 21, 971-983. [CrossRef] [PubMed]

12. Shanbhag, S.; Ambinder, R.F. Hodgkin lymphoma: A review and update on recent progress. CA Cancer J. Clin. 2018, 68, 116-132. [CrossRef] [PubMed]

13. Zahid, U.; Akbar, F.; Amaraneni, A.; Husnain, M.; Chan, O.; bin Riaz, I.; McBride, A.; Iftikhar, A.; Anwer, F. A Review of Autologous Stem Cell Transplantation in Lymphoma. Curr. Hematol. Malig. Rep. 2017, 12, 217-226. [CrossRef]

14. Fermé, C.; Mounier, N.; Diviné, M.; Brice, P.; Stamatoullas, A.; Reman, O.; Jaubert, J.; Lederlin, P.; Colin, P.; Berger, F.; et al. Intensive salvage therapy with high-dose chemotherapy for patients with advanced Hodgkin's disease in relapse or failure after initial chemotherapy: Results of the Groupe d'Études des Lymphomes de l'Adulte H89 trial. J. Clin. Oncol. 2002, 20, 467-475. [CrossRef] [PubMed]

15. Rancea, M.; Monsef, I.; von Tresckow, B.; Engert, A.; Skoetz, N. High-dose chemotherapy followed by autologous stem cell transplantation for patients with relapsed/refractory Hodgkin lymphoma. Cochrane Database Syst. Rev. 2013, 6, CD009411. [CrossRef] [PubMed]

16. Hahn, T.; McCarthy, P.L.; Carreras, J.; Zhang, M.-J.; Lazarus, H.M.; Laport, G.G.; Montoto, S.; Hari, P.N. Simplified Validated Prognostic Model for Progression-Free Survival after Autologous Transplantation for Hodgkin Lymphoma. Biol. Blood Marrow Transpl. 2013, 19, 1740-1744. [CrossRef] [PubMed]

17. Josting, A.; Franklin, J.; May, M.; Koch, P.; Beykirch, M.K.; Heinz, J.; Rudolph, C.; Diehl, V.; Engert, A. New Prognostic Score Based on Treatment Outcome of Patients With Relapsed Hodgkin's Lymphoma Registered in the Database of the German Hodgkin's Lymphoma Study Group. J. Clin. Oncol. 2002, 20, 221-230. [CrossRef]

18. Hahn, T.; Benekli, M.; Wong, C.; Moysich, K.B.; Hyland, A.; Michalek, A.M.; Alam, A.; Baer, M.R.; Bambach, B.; Czuczman, M.S.; et al. A prognostic model for prolonged event-free survival after autologous or allogeneic blood or marrow transplantation for relapsed and refractory Hodgkin's disease. Bone Marrow Transpl. 2005, 35, 557-566. [CrossRef]

19. Lazarus, H.M.; Loberiza, F.R.; Zhang, M.-J.; O Armitage, J.; Ballen, K.K.; Bashey, A.; Bolwell, B.J.; Burns, L.J.; O Freytes, C.; Gale, R.P.; et al. Autotransplants for Hodgkin's disease in first relapse or second remission: A report from the autologous blood and marrow transplant registry (ABMTR). Bone Marrow Transpl. 2001, 27, 387-396. [CrossRef]

20. Sureda, A.; Constans, M.; Iriondo, A.; Arranz, R.; Caballero, M.D.; Vidal, M.J.; Petit, J.; López, A.; Lahuerta, J.J.; Carreras, E.; et al. Prognostic factors affecting long-term outcome after stem cell transplantation in Hodgkin's lymphoma autografted after a first relapse. Ann. Oncol. 2005, 16, 625-633. [CrossRef]

21. Moskowitz, C.H.; Walewski, J.; Nademanee, A.; Masszi, T.; Agura, E.; Holowiecki, J.; Abidi, M.H.; Chen, A.I.; Stiff, P.; Viviani, S.; et al. Five-year PFS from the AETHERA trial of brentuximab vedotin for Hodgkin lymphoma at high risk of progression or relapse. Blood 2018, 132, 2639-2642. [CrossRef] 
22. Chen, R.; Gopal, A.K.; Smith, S.E.; Ansell, S.M.; Rosenblatt, J.D.; Savage, K.J.; Connors, J.M.; Engert, A.; Larsen, E.K.; Huebner, D.; et al. Five-year survival and durability results of brentuximab vedotin in patients with relapsed or refractory Hodgkin lymphoma. Blood 2016, 128, 1562-1566. [CrossRef]

23. Herrera, A.F.; Chen, L.; Nieto, Y.; Holmberg, L.; Johnston, P.B.; Mei, M.; Popplewell, L.; Armenian, D.S.H.; Cao, T.; Farol, L.; et al. Consolidation with Nivolumab and Brentuximab Vedotin after Autologous Hematopoietic Cell Transplantation in Patients with High-Risk Hodgkin Lymphoma. Blood 2020, 136, 19-20. [CrossRef]

24. Kewalramani, T.; Nimer, S.D.; Zelenetz, A.D.; Malhotra, S.; Qin, J.; Yahalom, J.; Moskowitz, C.H. Progressive disease following autologous transplantation in patients with chemosensitive relapsed or primary refractory Hodgkin's disease or aggressive non-Hodgkin's lymphoma. Bone Marrow Transpl. 2003, 32, 673-679. [CrossRef]

25. Arai, S.; Fanale, M.; Devos, S.; Engert, A.; Illidge, T.; Borchmann, P.; Younes, A.; Morschhauser, F.; McMillan, A.; Horning, S.J. Defining a hodgkin lymphoma population for novel therapeutics after relapse from autologous hematopoietic cell transplant. Leuk. Lymphoma 2013, 54, 2531-2533. [CrossRef]

26. Reddy, N.M.; Perales, M.A. Stem cell transplantation in Hodgkin lymphoma. Hematol. Oncol. Clin. N. Am. 2014, $28,1097-1112$. [CrossRef] [PubMed]

27. Peggs, K.S.; Hunter, A.; Chopra, R.; Parker, A.; Mahendra, P.; Milligan, D.; Craddock, C.; Pettengell, R.; Dogan, A.; Thomson, K.J.; et al. Clinical evidence of a graft-versus-Hodgkin's-lymphoma effect after reduced-intensity allogeneic transplantation. Lancet 2005, 365, 1934-1941. [CrossRef]

28. Anderlini, P.; Swanston, N.; Rashid, A.; Bueso-Ramos, C.; Macapinlac, H.A.; Champlin, R.E. Evidence of a Graft-versus-Hodgkin Lymphoma Effect in the Setting of Extensive Bone Marrow Involvement. Biol. Blood Marrow Transpl. 2008, 14, 478-480. [CrossRef] [PubMed]

29. Urbano-Ispizua, A.; Pavletic, S.Z.; Flowers, M.E.; Klein, J.P.; Zhang, M.-J.; Carreras, J.; Montoto, S.; Perales, M.-A.; Aljurf, M.D.; Akpek, G.; et al. The Impact of Graft-versus-Host Disease on the Relapse Rate in Patients with Lymphoma Depends on the Histological Subtype and the Intensity of the Conditioning Regimen. Biol. Blood Marrow Transpl. 2015, 21, 1746-1753. [CrossRef]

30. Sureda, A.; Domenech, E.; Schmitz, N.; Dreger, P. The role of allogeneic stem cell transplantation in Hodgkin's lymphoma. Curr Treat. Options Oncol. 2014, 15, 238-247. [CrossRef] [PubMed]

31. Moskowitz, C.H. Should all patients with HL who relapse after ASCT be considered for allogeneic SCT? A consult, yes; A transplant, not necessarily. Blood Adv. 2018, 2, 821-824. [CrossRef] [PubMed]

32. Peggs, K.S. Should all patients with Hodgkin lymphoma who relapse after autologous SCT be considered for allogeneic SCT? Blood Adv. 2018, 2, 817-820. [CrossRef]

33. Sureda, A.; Canals, C.; Arranz, R.; Caballero, D.; Ribera, J.-M.; Brune, M.; Passweg, J.R.; Martino, R.; Valcarcel, D.; Besalduch, J.; et al. Allogeneic stem cell transplantation after reduced intensity conditioning in patients with relapsed or refractory Hodgkin's lymphoma. Results of the HDR-ALLO study-A prospective clinical trial by the Grupo Español de Linfomas/ Trasplante de Médula Osea. Haematologica 2012, 97, 310-317. [CrossRef] [PubMed]

34. Sureda, A.; Robinson, S.; Canals, C.; Carella, A.M.; Boogaerts, M.A.; Caballero, D.; Hunter, A.E.; Kanz, L.; Slavin, S.; Cornelissen J.J.; et al. Reduced-intensity conditioning compared with conventional allogeneic stem-cell transplantation in relapsed or refractory Hodgkin's lymphoma: An analysis from the lymphoma working party of the European Group for Blood and Marrow Transplantation. J. Clin. Oncol. 2008, 26, 455-462. [CrossRef] [PubMed]

35. Anderlini, P.; Saliba, R.; Acholonu, S.; Giralt, S.A.; Andersson, B.; Ueno, N.T.; Hosing, C.; Khouri, I.F.; Couriel, D.; De Lima, M.; et al. Fludarabine-melphalan as a preparative regimen for reduced-intensity conditioning allogeneic stem cell transplantation in relapsed and refractory Hodgkin's lymphoma: The updated M.D. Anderson Cancer Center experience. Haematologica 2008, 93, 257-264. [CrossRef] [PubMed]

36. Robinson, S.P.; Sureda, A.; Canals, C.; Russell, N.; Caballero, D.; Bacigalupo, A.; Iriondo, A.; Cook, G.; Pettitt, A.; Socie, G.; et al. Reduced intensity conditioning allogeneic stem cell transplantation for Hodgkin's lymphoma: Identification of prognostic factors predicting outcome. Haematologica 2009, 94, 230-238. [CrossRef]

37. Devetten, M.P.; Hari, P.N.; Carreras, J.; Logan, B.R.; van Besien, K.; Bredeson, C.N.; Freytes, C.O.; Gale, R.P.; Gibson, J.; Giralt, S.A.; et al. Unrelated Donor Reduced-Intensity Allogeneic Hematopoietic Stem Cell Transplantation for Relapsed and Refractory Hodgkin Lymphoma. Biol. Blood Marrow Transpl. 2009, 15, 109-117. [CrossRef]

38. Marcais, A.; Porcher, R.; Robin, M.; Mohty, M.; Michalet, M.; Blaise, D.; Tabrizi, R.; Clement, L.; Ceballos, P.; Daguindau, E.; et al. Impact of disease status and stem cell source on the results of reduced intensity conditioning transplant for Hodgkin's lymphoma: A retrospective study from the French Society of Bone Marrow Transplantation and Cellular Therapy (SFGM-TC). Haematologica 2013, 98, 1467-1475. [CrossRef]

39. Kako, S.; Izutsu, K.; Kato, K.; Kim, S.-W.; Mori, T.; Fukuda, T.; Kobayashi, N.; Taji, H.; Hashimoto, H.; Kondo, T.; et al. The role of hematopoietic stem cell transplantation for relapsed and refractory Hodgkin lymphoma. Am. J. Hematol. 2015, 90, 132-138. [CrossRef]

40. Sarina, B.; Castagna, L.; Farina, L.; Patriarca, F.; Benedetti, F.; Carella, A.M.; Falda, M.; Guidi, S.; Ciceri, F.; Bonini, A.; et al. Allogeneic transplantation improves the overall and progression-free survival of Hodgkin lymphoma patients relapsing after autologous transplantation: A retrospective study based on the time of HLA typing and donor availability. Blood 2010, 115, 3671-3677. [CrossRef] 
41. Burroughs, L.M.; O’Donnell, P.V.; Sandmaier, B.M.; Storer, B.E.; Luznik, L.; Symons, H.J.; Jones, R.J.; Ambinder, R.F.; Maris, M.B.; Blume, K.G.; et al. Comparison of Outcomes of HLA-Matched Related, Unrelated, or HLA-Haploidentical Related Hematopoietic Cell Transplantation following Nonmyeloablative Conditioning for Relapsed or Refractory Hodgkin Lymphoma. Biol. Blood Marrow Transpl. 2008, 14, 1279-1287. [CrossRef]

42. Freytes, C.O.; Loberiza, F.R.; Rizzo, J.D.; Bashey, A.; Bredeson, C.N.; Cairo, M.S.; Gale, R.P.; Horowitz, M.M.; Klumpp, T.R.; Martino, R.; et al. Myeloablative allogeneic hematopoietic stem cell transplantation in patients who experience relapse after autologous stem cell transplantation for lymphoma: A report of the International Bone Marrow Transplant Registry. Blood 2004, 104, 3797-3803. [CrossRef]

43. Kanakry, C.G.; Fuchs, E.J.; Luznik, L. Modern approaches to HLA-haploidentical blood or marrow transplantation. Nat. Rev. Clin. Oncol. 2016, 13, 10-24. [CrossRef] [PubMed]

44. Ciurea, S.O.; Zhang, M.-J.; Bacigalupo, A.A.; Bashey, A.; Appelbaum, F.R.; Aljitawi, O.S.; Armand, P.; Antin, J.H.; Chen, J.; Devine, S.M.; et al. Haploidentical transplant with posttransplant cyclophosphamide vs matched unrelated donor transplant for acute myeloid leukemia. Blood 2015, 126, 1033-1040. [CrossRef] [PubMed]

45. Paviglianiti, A.; Maio, K.T.; Rocha, V.; Gehlkopf, E.; Milpied, N.; Esquirol, A.; Chevallier, P.; Blaise, D.; Gac, A.-C.; Leblond, V.; et al Outcomes of Advanced Hodgkin Lymphoma after Umbilical Cord Blood Transplantation: A Eurocord and EBMT Lymphoma and Cellular Therapy \& Immunobiology Working Party Study. Biol. Blood Marrow Transpl. 2018, 24, 2265-2270. [CrossRef]

46. Luznik, L.; O’Donnell, P.V.; Symons, H.J.; Chen, A.R.; Leffell, M.S.; Zahurak, M.; Gooley, T.A.; Piantadosi, S.; Kaup, M.; Ambinder, R.F.; et al. HLA-Haploidentical Bone Marrow Transplantation for Hematologic Malignancies Using Nonmyeloablative Conditioning and High-Dose, Posttransplantation Cyclophosphamide. Biol. Blood Marrow Transpl. 2008, 14, 641-650. [CrossRef] [PubMed]

47. Baron, F.; Storb, R.; Storer, B.E.; Maris, M.B.; Niederwieser, D.; Shizuru, J.A.; Chauncey, T.R.; Bruno, B.; Forman, S.J.; McSweeney, P.A.; et al. Factors associated with outcomes in allogeneic hematopoietic cell transplantation with nonmyeloablative conditioning after failed myeloablative hematopoietic cell transplantation. J. Clin. Oncol. 2006, 24, 4150-4157. [CrossRef] [PubMed]

48. Feinstein, L.C.; Sandmaier, B.M.; Maloney, D.G.; Maris, M.B.; Gooley, T.A.; Chauncey, T.R.; Hegenbart, U.; McSweeney, P.A.; Stuart, M.J.; Forman, S.J.; et al. Allografting after nonmyeloablative conditioning as a treatment after a failed conventional hematopoietic cell transplant. Biol. Blood Marrow Transpl. 2003, 9, 266-272. [CrossRef] [PubMed]

49. Messer, M.; Steinzen, A.; Vervölgyi, E.; Lerch, C.; Richter, B.; Dreger, P.; Herrmann-Frank, A. Unrelated and alternative donor allogeneic stem cell transplant in patients with relapsed or refractory Hodgkin lymphoma: A systematic review. Leuk. Lymphoma 2014, 55, 296-306. [CrossRef]

50. Martínez, C.; Gayoso, J.; Canals, C.; Finel, H.; Peggs, K.; Dominietto, A.; Castagna, L.; Afanasyev, B.; Robinson, S.; Blaise, D.; et al. Post-transplantation cyclophosphamide-based haploidentical transplantation as alternative to matched sibling or unrelated donor transplantation for hodgkin lymphoma: A registry study of the lymphoma working party of the european society for blood and marr. J. Clin. Oncol. 2017, 35, 3425-3432. [CrossRef]

51. Ahmed, S.; Kanakry, J.A.; Ahn, K.W.; Litovich, C.; Abdel-Azim, H.; Aljurf, M.; Bacher, V.U.; Bejanyan, N.; Cohen, J.B.; Farooq, U.; et al. Lower Graft-versus-Host Disease and Relapse Risk in Post-Transplant Cyclophosphamide-Based Haploidentical versus Matched Sibling Donor Reduced-Intensity Conditioning Transplant for Hodgkin Lymphoma. Biol. Blood Marrow Transpl. 2019, 25, 1859-1868. [CrossRef] [PubMed]

52. Ciurea, S.O.; Kongtim, P.; Srour, S.; Saini, N.Y.; Im, J.; Ramdial, J.; Khouri, I.; Anderlini, P.; Popat, U.; Hosing, C.; et al. Can we cure refractory Hodgkin's lymphoma with transplantation? Bone Marrow Transpl. 2021, 56, 278-281. [CrossRef] [PubMed]

53. Queirolo, P.; Boutros, A.; Tanda, E.; Spagnolo, F.; Quaglino, P. Immune-checkpoint inhibitors for the treatment of metastatic melanoma: A model of cancer immunotherapy. Semin. Cancer Biol. 2019, 59, 290-297. [CrossRef] [PubMed]

54. Atkins, M.B.; Clark, J.I.; Quinn, D.I. Immune checkpoint inhibitors in advanced renal cell carcinoma: Experience to date and future directions. Ann. Oncol. 2017, 28, 1484-1494. [CrossRef]

55. Doroshow, D.B.; Sanmamed, M.F.; Hastings, K.; Politi, K.; Rimm, D.L.; Chen, L.; Melero, I.; Schalper, K.A.; Herbst, R.S. Immunotherapy in non-small cell lung cancer: Facts and hopes. Clin. Cancer Res. 2019, 25, 4592-4602. [CrossRef]

56. Meti, N.; Esfahani, K.; Johnson, N.A. The role of immune checkpoint inhibitors in classical hodgkin lymphoma. Cancers 2018, 10, 204. [CrossRef] [PubMed]

57. Merryman, R.W.; Kim, H.T.; Zinzani, P.L.; Carlo-Stella, C.; Ansell, S.M.; Perales, M.-A.; Avigdor, A.; Halwani, A.; Houot, R.; Marchand, T.; et al. Safety and efficacy of allogeneic hematopoietic stem cell transplant after PD-1 blockade in relapsed/refractory lymphoma. Blood 2017, 129, 1380-1388. [CrossRef]

58. Haverkos, B.M.; Abbott, D.; Hamadani, M.; Armand, P.; Flowers, M.E.; Merryman, R.; Kamdar, M.; Kanate, A.S.; Saad, A.; Mehta, A.; et al. PD-1 blockade for relapsed lymphoma post-allogeneic hematopoietic cell transplant: High response rate but frequent GVHD. Blood 2017, 130, 221-228. [CrossRef]

59. Herbaux, C.; Gauthier, J.; Brice, P.; Drumez, E.; Ysebaert, L.; Doyen, H.; Fornecker, L.; Bouabdallah, K.; Manson, G.; Ghesquières, H.; et al. Efficacy and tolerability of nivolumab after allogeneic transplantation for relapsed Hodgkin lymphoma. Blood 2017, 129, 2471-2478. [CrossRef]

60. Dada, R.; Usman, B. Allogeneic hematopoietic stem cell transplantation in $\mathrm{r} / \mathrm{r}$ Hodgkin lymphoma after treatment with checkpoint inhibitors: Feasibility and safety. Eur. J. Haematol. 2019, 102, 150-156. [CrossRef] 
61. Ijaz, A.; Khan, A.Y.; Malik, S.U.; Faridi, W.; Fraz, M.A.; Usman, M.; Tariq, M.J.; Durer, S.; Russ, A.; Parr, N.N.C.; et al. Significant Risk of Graft-versus-Host Disease with Exposure to Checkpoint Inhibitors before and after Allogeneic Transplantation. Biol. Blood Marrow Transpl. 2019, 25, 94-99. [CrossRef] [PubMed]

62. Merryman, R.W.; Castagna, L.; Giordano, L.; Ho, V.T.; Corradini, P.; Guidetti, A.; Casadei, B.; Bond, D.A.; Jaglowski, S.; Spinner M.A.; et al. Allogeneic transplantation after PD-1 blockade for classic Hodgkin lymphoma. Leukemia 2021, 35, 2672-2683. [CrossRef]

63. Ramos, C.A.; Grover, N.S.; Beaven, A.W.; Lulla, P.D.; Wu, M.-F.; Ivanova, A.; Wang, T.; Shea, T.C.; Rooney, C.M.; Dittus, C.; et al Anti-CD30 CAR-T Cell Therapy in Relapsed and Refractory Hodgkin Lymphoma. J. Clin. Oncol. 2020, 38, 3794-3804. [CrossRef] [PubMed]

64. Kerbauy, L.N.; Marin, N.D.; Kaplan, M.; Banerjee, P.P.; Berrien-Elliott, M.M.; Becker-Hapak, M.K.; Basar, R.; Foster, M.; Melo, L.G.; Neal, C.C.; et al. Combining AFM13, a bispecific CD30/CD16 antibody, with cytokine-activated blood and cord blood-derived NK cells facilitates CAR-like responses against CD30+ malignancies. Clin. Cancer Res. 2021, 27, 3744-3756. [CrossRef] [PubMed] 